\title{
Amperometric L-glutamate sensor using a novel L-glutamate oxidase from Streptomyces platensis NTU 3304
}

\author{
Chien-Yuan Chen ${ }^{*}$ and Yuan-Chi Su \\ Department of Agricultural Chemistry, National Taiwan University, 1, Sec. 4, Roosevelt Road, Taipei (Taiwan)
}

(Received 27th June 1990)

\begin{abstract}
Streptomyces platensis NTU 3304, isolated from soil samples, produces extracellular L-glutamate oxidase in liquid culture. Strains of this species have never been reported to be able to produce this enzyme. The purified enzyme was immobilized onto a cellulose triacetate membrane which was held at an oxygen electrode. The sensor was specific to L-glutamate in accordance with the properties of the novel L-glutamate oxidase. The time required for each assay in batch operation was less than $3 \mathrm{~min}$. A linear relationship is observed between the decrease in dissolved oxygen and the concentration of $\mathrm{L}$-glutamate between 20 and $140 \mathrm{mg}^{-1}$ (ca. 0.12 and $0.84 \mathrm{mM}$ ). The sensor retained $95 \%$ of its original activity after 400 assays over a period of 3 weeks. The sensor was applied to determine the concentration of L-glutamate in broth samples during L-glutamic acid fermentation. Good correlations were achieved between results obtained with the sensor and by enzymatic analysis using glutamate dehydrogenase.
\end{abstract}

Keywords: Amperometry; Enzyme electrodes; Glutamate

The production of $\mathbf{L}$-glutamic acid by fermentation has grown rapidly in order to meet increased world needs for monosodium L-glutamate. The determination of L-glutamic acid is important in process and quality control. At present, L-glutamate decarboxylase and L-glutamate dehydrogenase are used in conjunction with either a respirator or automated spectrophotometric analyser to determine L-glutamic acid. However, both of these enzymes have disadvantages, including poor substrate specificity and the requirement for expensive cofactors. In addition, the instrumentation for these techniques is expensive and complicated.

In general, L-glutamic acid is a poor substrate for all kinds of L-amino acid oxidases. L-Glutamate oxidase activity was first discovered in the membrane fragment of Azotobacter vinelandii by Jurtshuk and McManus [1]. However, this enzyme also catalyses oxidizing reactions of several other amino acids and involves a four-electron transfer process because no hydrogen peroxide was found.

More recently, a typical L-glutamate oxidase was isolated by Matsuzaki et al. [2] in a wheat bran culture extract of Streptomyces violascens. This enzyme catalyses the oxidative deamination of L-glutamate to produce hydrogen peroxide as follows:

$$
\begin{aligned}
\text { L-glutamate }+\mathrm{O}_{2}+\mathrm{H}_{2} \mathrm{O} \rightarrow & \alpha \text {-ketoglutarate } \\
& +\mathrm{NH}_{3}+\mathrm{H}_{2} \mathrm{O}_{2}
\end{aligned}
$$

However, the enzyme from this strain also exhibits measurable activity for L-glutamine and L-histidine. Similar catalytic activity was observed by Kusakabe et al. [3] in a wheat bran culture extract of the strain Streptomyces sp. X-119-6. The specificity of this enzyme is far better than of other enzymes. In addition to L-glutamate, only L- 
aspartate was oxidized $(0.6 \%$ at $\mathrm{pH} 7.4$, but not detectable at $\mathrm{pH}$ 6.0).

In this work, a strain which produces extracellular L-glutamate oxidase in a liquid culture, NTU 3304 [4], was isolated from soil. This strain was identified as Streptomyces platensis from its morphological and physiological properties. Strains of this species have never been reported to be able to produce L-glutamate oxidase. However, the specificity of the enzyme produced by NTU 3304 is better than that of the other enzymes mentioned above. This paper describes the first biosensor utilizing L-glutamate oxidase produced by a strain of this species.

In recent years, biosensors have attracted much attention for the determination of organic materials. L-Glutamate sensors have been constructed using enzymes [5], microbial cells [6] and plant tissues [7]. Enzyme sensors exhibit the highest degree of specificity and have proved to be the most widely applicable. To this end, L-glutamate decarboxylase [8], L-glutamate dehydrogenase [9], glutamate synthetase $[10,11]$ and L-glutamate oxidase [12] have been used to construct enzymatic sensors.

In this paper the use of the L-glutamate oxidase produced by Streptomyces platensis NTU 3304 is described. The specificity of the enzyme from this strain is very high and L-glutamate is oxidized exclusively. Purified L-glutamate oxidase from the culture broth of strain NTU 3304 was subsequently immobilized onto cellulose triacetate to make an immobilized enzyme membrane. An enzyme electrode specific to L-glutamate was fabricated by holding the enzyme membrane in close proximity to an oxygen sensor. This sensor, in accordance with the excellent properties of the novel L-glutamate oxidase, exhibits high sensitivity, a fast response time and good stability. In addition, the sensor is easy to assemble.

Previously, L-glutamate oxidase has been used to determine the L-glutamate content in soy sauce [13] and food products [14]. It has also been used to determine the activities of enzymes which produce or consume L-glutamate in their catalytic reactions [15]. It is hoped that this sensor will be suitable for monitoring the process of L-glutamic acid fermentation.

\section{EXPERIMENTAL}

\section{Equipment}

Dissolved oxygen was measured using a Xertex Model 2100 multi-range analyser (Delta Scientific, U.S.A.). Responses were recorded with a Model 8700 dual-pen recorder (Knauer, F.R.G.). A Model PC-351 magnetic stirrer (Corning, Corning, NY) with a PTFE-coated stirring disk was used to mix the buffer and sample during operation. The temperature of the buffer, sample and reaction cell was maintained at $28^{\circ} \mathrm{C}$ with a Model 811 thermostated water-bath (Hotech, Taiwan) and a Model CK-101G water-sinking pump (Liang-Chi, Taiwan). Buffer solutions were air saturated at that temperature. Spectrophotometric measurements were made using a Model UV 150-02 double-beam spectrophotometer (Shimadzu, Tokyo). L-Glutamate oxidase was produced by incubating Streptomyces platensis NTU 3304 in a Model MD 300 jar fermenter (Marubishi, Tokyo).

\section{Reagents}

$o$-Dianisidine, peroxidase, hydrogen peroxide, 1,8-diaminooctane, glutamate dehydrogenase (E.C. 1.4.1.3) and the amino acids listed in Table 2 were obtained from Sigma (St. Louis, MO). 1,4-Diaminobutane, 1,6-diaminohexane and 1,12-diaminododecane were purchased from Tokyo Kasei (Tokyo). Cellulose triacetate was obtained from Eastman-Kodak (Rochester, NY). A 50\% solution of glutaraldehyde in water was obtained from Fluka (Buchs, Switzerland), dichloromethane from Alps Chemical (Taiwan), ethylenediamine from Wako (Osaka), tetraethylenepentamine from Hayashi (Tokyo) and monosodium L-glutamate from Wei-Chuang Food (Taiwan). All other reagents were of the highest grade commercially available.

\section{Determination of the activity of L-glutamate oxidase}

The activity of L-glutamate oxidase was determined using a spectrophotometric method based on the production of hydrogen peroxide. A reaction mixture containing $1.5 \mathrm{ml}$ of $o$-dianisidine (132 $\left.\mathrm{mg} \mathrm{l}^{-1}\right), 1.5 \mathrm{ml}$ of phosphate buffer $(0.2 \mathrm{M}$, pH 7.0), $0.2 \mathrm{ml}$ of peroxidase $\left(9 \mathrm{U} \mathrm{ml}^{-1}\right)$ and 0.2 $\mathrm{ml}$ of monosodium L-glutamate $(0.5 \mathrm{M})$ was in- 
cubated at $50^{\circ} \mathrm{C}$ in a water-bath. Enzyme solution $(0.2 \mathrm{ml})$ was added and the mixture was incubated at $50^{\circ} \mathrm{C}$ for $10 \mathrm{~min}$. The concentration of hydrogen peroxide. was determined by measuring the absorbance at $436 \mathrm{~nm}$. Enzyme activity was determined by comparison with a calibration graph for hydrogen peroxide. One unit of enzyme activity is defined as the amount of enzyme that produces $1 \mu \mathrm{mol}$ of hydrogen peroxide in $1 \mathrm{~min}$ under the conditions mentioned above.

\section{Preparation of cellulose triacetate membrane}

A $0.2-\mathrm{g}$ amount of cellulose triacetate was dissolved in $10 \mathrm{ml}$ of dichloromethane to obtain a viscous solution and $0.05 \mathrm{ml}$ of $50 \%$ glutaraldehyde solution was added. Various specified compounds with amino groups on both ends, including ethylenediamine, 1,4-diaminobutane, 1,6-diaminohexane, 1,8-diaminooctane, tetraethylenepentamine and 1,12-diaminododecane, were added at a concentration of $0.1 \mathrm{M}$ to investigate their ability to act as spacers. The homogeneous solution was cast on a glass plate to form a film 300 $\mu \mathrm{m}$ thick. The preparation was allowed to stand for 3 days at room temperature to complete the interactions between carrier, spacer and glutaraldehyde molecules, then the membrane was completely removed from the glass plate and cut into discs of $10 \mathrm{~mm}$ diameter. The discs were stored in a desiccator at room temperature.

\section{Enzyme immobilization}

Cellulose triacetate membrane was immersed in $10 \%$ glutaraldehyde solution for $2 \mathrm{~h}$ at room tem- perature. The disc was thoroughly washed with distilled water and then transferred to an Lglutamate oxidase solution (10 $\left.\mathrm{U} \mathrm{ml}^{-1}\right)$. Enzyme immobilization was completed in $2 \mathrm{~h}$ at room temperature. The enzyme membrane was then washed with phosphate buffer ( $50 \mathrm{mM}, \mathrm{pH} 7.0)$ and stored in the same buffer at $4^{\circ} \mathrm{C}$.

\section{Assembly of the sensor}

The immobilized enzyme membrane was attached to a gas-permeable PTFE membrane of an oxygen electrode and covered with a polycarbonate ultrafiltration membrane (pore size 0.03 $\mu \mathrm{m}$, thickness 6-7 $\mu \mathrm{m}$; Nuclepore, Pleasanton, CA) for protection. A piece of polyethylene net secured by a rubber O-ring was used to fix the three membranes firmly on the tip of the electrode.

\section{Operating system}

Figure 1 shows a schematic diagram of the operating system used. The enzyme electrode was fixed in a water-jacketted glass reactor which was filled with $5 \mathrm{ml}$ of air-saturated phosphate buffer solution (50 mM, pH 7.0). The temperature was maintained at $28^{\circ} \mathrm{C}$ with a thermostated circulating water-bath. Magnetic stirring was used during operation.

\section{Operating procedure}

A baseline was obtained in buffer solution. The reaction was initiated by the injection of sample solution into the buffer solution using a micro-

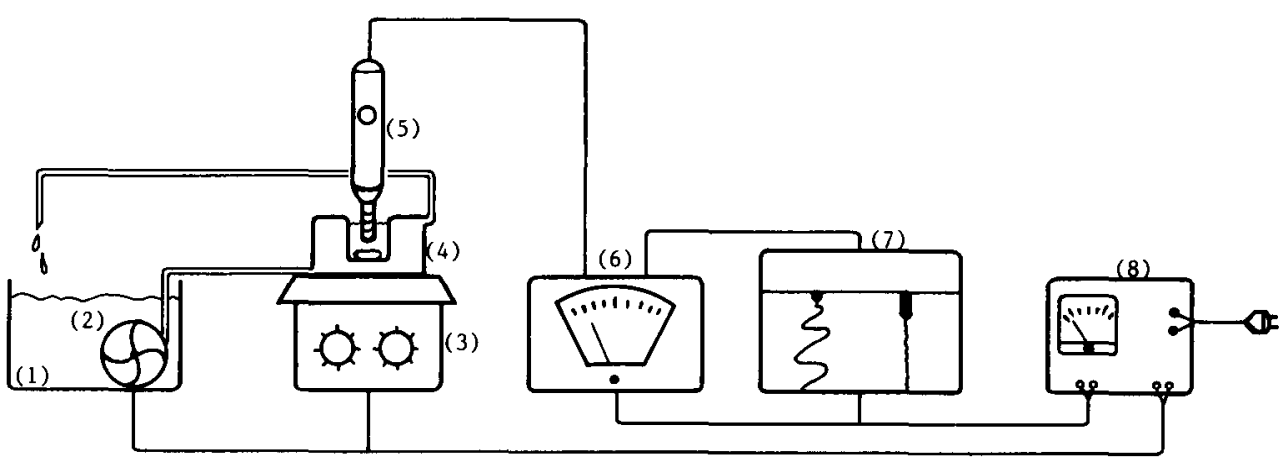

Fig. 1. Schematic diagram of the sensor system. (1) Thermostated water-bath; (2) water sinking pump; (3) hot-plate stirrer; (4) water-jacketted glassware; (5) dissolved oxygen (D.O.) probe; (6) D.O. analyser; (7) dual-pen recorder; (8) current stabilizer. 
TABLE 1

Effect of various spacer molecules on the response of the sensor ${ }^{\text {a }}$

\begin{tabular}{lc}
\hline Spacer & Relative response (\%) \\
\hline Ethylenediamine & 76 \\
1,4-Diaminobutane & 29 \\
1,6-Diaminohexane & 32 \\
1,8-Diaminooctane & 68 \\
Tetraethylenepentamine & 44 \\
1,12-Diaminododecane & 100
\end{tabular}

axperiments were done in $50 \mathrm{mM}$ phosphate buffer (pH 7.0) at $28^{\circ} \mathrm{C}$. The concentration of monosodium L-glutamate was $100 \mathrm{mg} \mathrm{l}^{-1}$ (ca. $0.6 \mathrm{mM}$ ).

syringe. The change in dissolved oxygen concentration was recorded using a chart recorder.

\section{RESULTS AND DISCUSSION}

Optimum conditions for preparing immobilized enzyme membrane

Optimum conditions were investigated stepwise as described previously [16]. 1,12-Diaminododecane gave the best results for enzyme immobilization, as shown in Table 1, and was subsequently chosen as the spacer molecule. The efficiency of enzyme immobilization using diamino compounds as spacer molcculcs was not related to the length of the carbon chain of the spacer. Why 1,12-diaminododecane gave the best results is not known. Other conditions, including concentrations of cel-

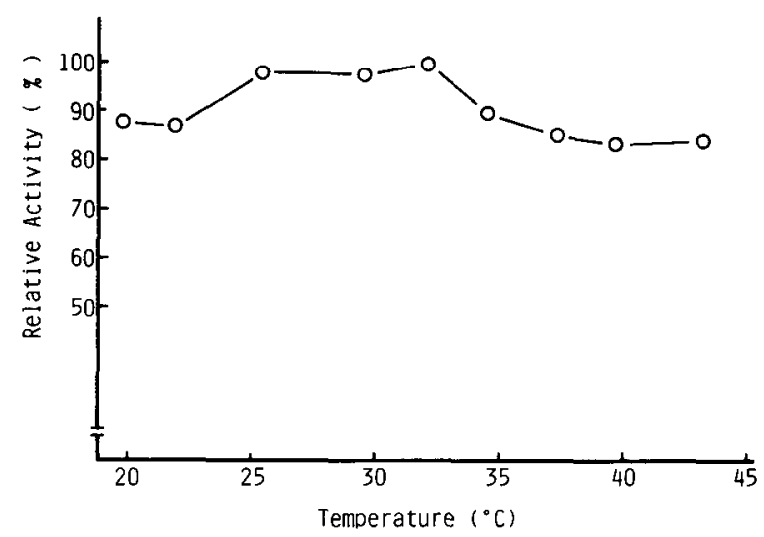

Fig. 2. Effect of temperature on the response of the L-glutamate sensor. Experiments were done in $50 \mathrm{mM}$ phosphate buffer ( $\mathrm{pH} \mathrm{7.0)}$ ). The concentration of monosodium L-glutamate was $100 \mathrm{mg}^{-1}$ (ca. $0.6 \mathrm{mM}$ ).

lulose triacetate, glutaraldehyde and spacer, thickness of casting and the operating temperature of each step were investigated in order to determine the optimum preparation of immobilized enzyme membranes.

\section{Substrate specificity of the sensor}

The relative responses of this sensor to some other amino acids are shown in Table 2. The electrode was specific to L-glutamate; other amino acids gave no responsc. The difference betwecn the responses for monosodium L-glutamate and L-glutamic acid may be due to the difference in purity and the content of sodium ion. Mono-

TABLE 2

Substrate specificity of the sensor ${ }^{\text {a }}$

\begin{tabular}{ll}
\hline Substrate & Relative response (\%) \\
\hline L-Glutamic acid & 100 \\
Monosodium L-glutamate & 101 \\
L-Glutamine, D-glutamic acid, L-tryptophan, & \\
L-asparagine, L-aspartic acid, glycine, & \\
DL-serine, L-lysine, L-phenylalanine, & \\
DL-threonine, L-valine, L-proline, & \\
L-isoleucine, L-leucine, L-methionine, & \\
L-alanine, L-cysteine, L-histidine, & 0 \\
L-tyrosine &
\end{tabular}

\footnotetext{
a Sample concentration, $0.2 \mathrm{mM}$ for L-histidine and L-tyrosine and $0.4 \mathrm{mM}$ for other amino acids. Experiments were done in $50 \mathrm{mM}$ phosphate buffer (pH 7.0) at $28^{\circ} \mathrm{C}$.
} 
sodium L-glutamate was used during these experiments because the difference in response between it and L-glutamic acid was small, it has a higher solubility and it is cheaper and easier to obtain.

\section{Effects of temperature, $p H$ and metal ions}

Figures 2 and 3 and Table 3 show the effects of temperature, $\mathrm{pH}$ and metal ions on the response of the sensor. The sensor maintained its optimum conditions in the temperature range $26-32^{\circ} \mathrm{C}$. The optimum $\mathrm{pH}$ was 7.0. No significant difference in responses at $\mathrm{pH} 7.0$ was observed between citrate, phosphate and universal buffers. The response of the sensor decreased sharply in both the acidic and alkaline directions. All subsequent measurements were made at $28^{\circ} \mathrm{C}$ in 50 $\mathrm{mM}$ phosphate buffer ( $\mathrm{pH} 7.0$ ). The response of the sensor was found to be significantly inhibited by both $\mathrm{Hg}$ (II) and $\mathrm{Cu}$ (II) ions at $2 \mathrm{mM}$ concentration. In addition, $\mathrm{Ni}$ (II) ions at the same concentration caused a $13 \%$ reduction in the response. However, these ions are usually not present in significant concentrations during the fermentation process.

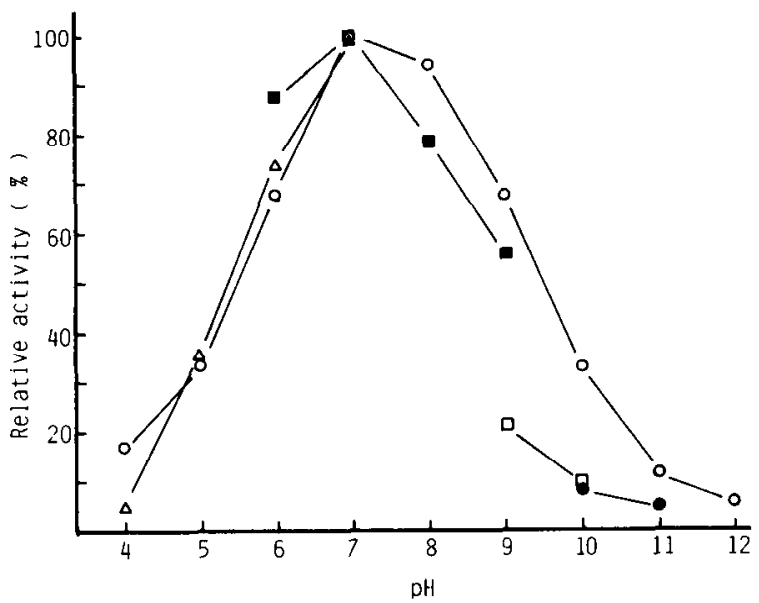

Fig. 3. Effect of $\mathrm{pH}$ on the response of the $\mathrm{L}$-glutamate sensor. Buffers used: $50 \mathrm{mM}$ citrate buffer $(\Delta)$; phosphate buffer $(\square)$; carbonate buffer [(口) $\mathrm{Na}_{2} \mathrm{CO}_{3}-\mathrm{NaHCO}_{3}$; (๑) $\mathrm{NaHCO}_{3}-$ $\mathrm{NaOH}]$ and universal buffer $(\mathrm{O})$. Experiments were done at $28^{\circ} \mathrm{C}$. The concentration of monosodium $\mathrm{L}$-glutamate was 100 $\mathrm{mg} 1^{-1}$ (ca. $0.6 \mathrm{mM}$ ).
TABLE 3

Effect of metal ions on response of the sensor ${ }^{2}$

\begin{tabular}{llr}
\hline Metal ions & Added as & Relative response (\%) \\
\hline Blank & & 100 \\
$\mathrm{Li}^{+}$ & $\mathrm{Li}_{2} \mathrm{SO}_{4}$ & 105 \\
$\mathrm{Na}^{+}$ & $\mathrm{NaCl}$ & 102 \\
$\mathrm{~K}^{+}$ & $\mathrm{KCl}$ & 105 \\
$\mathrm{Mg}^{2+}$ & $\mathrm{MgSO}_{4} \cdot 7 \mathrm{H}_{2} \mathrm{O}$ & 105 \\
$\mathrm{Ca}^{2+}$ & $\mathrm{CaCl}_{2} \cdot 2 \mathrm{H}_{2} \mathrm{O}$ & 112 \\
$\mathrm{Ba}^{2+}$ & $\mathrm{BaSO}_{4}$ & 95 \\
$\mathrm{Mn}^{2+}$ & $\mathrm{MnCl}_{2} \cdot 4 \mathrm{H}_{2} \mathrm{O}$ & 114 \\
$\mathrm{Ni}^{2+}$ & $\mathrm{NiSO}_{4} \cdot x \mathrm{H}_{2} \mathrm{O}$ & 87 \\
$\mathrm{Zn}^{2+}$ & $\mathrm{ZnCl}_{2}$ & 109 \\
$\mathrm{Cd}^{2+}$ & $\mathrm{CdCl}_{2} \cdot \frac{5}{2} \mathrm{H}_{2} \mathrm{O}$ & 105 \\
$\mathrm{Co}^{2+}$ & $\left.\mathrm{Co}^{2+} \mathrm{NO}_{3}\right)_{2}$ & 102 \\
$\mathrm{Cu}^{2+}$ & $\mathrm{CuSO}_{4} \cdot 5 \mathrm{H}_{2} \mathrm{O}$ & 16 \\
$\mathrm{~Pb}^{2+}$ & ${\mathrm{Pb}\left(\mathrm{CH}_{3} \mathrm{COO}_{2} \cdot 3 \mathrm{H}_{2} \mathrm{O}\right.}^{2}$ & 102 \\
$\mathrm{Fe}^{2+}$ & $\mathrm{FeSO}_{4} \cdot 7 \mathrm{H}_{2} \mathrm{O}$ & 92 \\
$\mathrm{Fe}^{3+}$ & $\mathrm{FeCl}_{3}$ & 98 \\
$\mathrm{Hg}^{2+}$ & $\mathrm{HgCl}_{2}$ & 11 \\
\hline
\end{tabular}

The concentration of each metal ion was $2 \mathrm{mM}$, assuming that $x=5$ in $\mathrm{NiSO}_{4} \cdot x \mathrm{H}_{2} \mathrm{O}$. Experiments were done in $50 \mathrm{mM}$ phosphate buffer (pH 7.0) at $28^{\circ} \mathrm{C}$ using $100 \mathrm{mg} \mathrm{l}^{-1}$ (ca. 0.6 $\mathrm{mM}$ ) monosodium L-glutamate as the sample.

\section{Response curves}

Figure 4 shows the response curves for sample concentrations between 20 and $200 \mathrm{mg}^{-1}$ (ca. 0.12 to $1.2 \mathrm{mM}$ ). The concentrations shown indicate the final concentrations of monosodium Lglutamate in the electrochemical cell. The time required to reach the steady state was dependent on the concentration of the sample solution. Reactions were completed within $3 \mathrm{~min}$. The time needed to re-establish the initial dissolved oxygen (D.O.) baseline after transferring the enzyme electrode to a fresh reaction buffer was about $90 \mathrm{~s}$. Figure 4 also shows the concentration range of monosodium L-glutamate from 20 to $140 \mathrm{mg} \mathrm{l}^{-1}$ over which there was a linear relationship between decrease in D.O. and concentration of monosodium L-glutamate. The calibration graph is shown in Fig. 5. Further, instead of transferring the enzyme electrode to fresh reaction buffer at the end of a determination, a second sample was injected into the first reaction buffer to investigate whether the sensor still responded in a linear fashion without re-establishing the baseline. The results shown in Fig. 6 indicate this to be the case. 


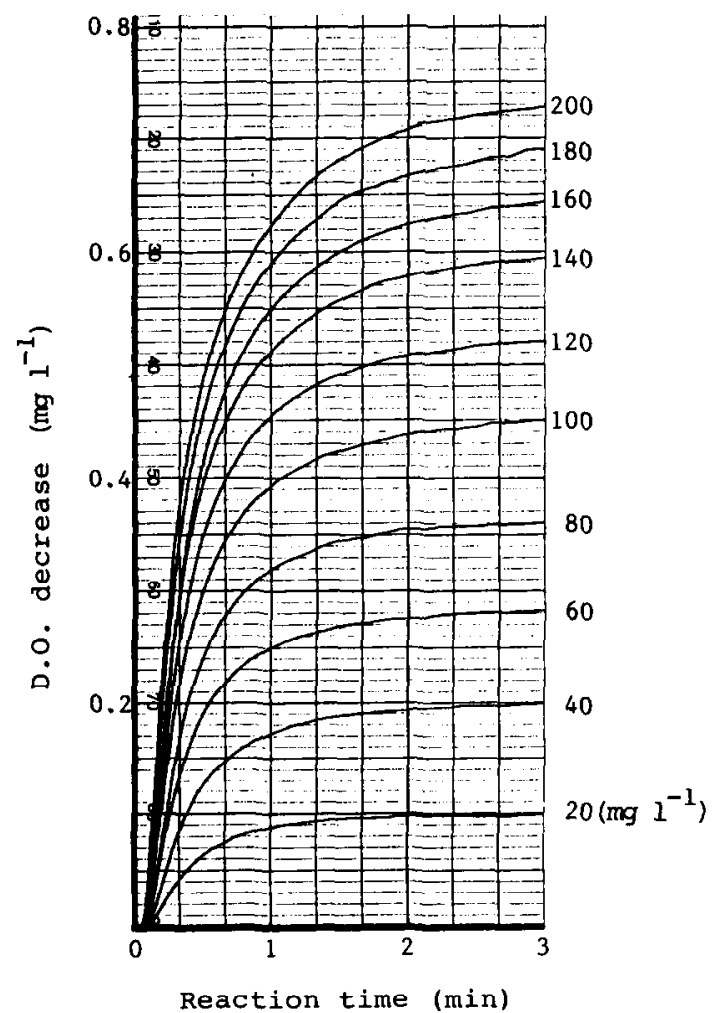

Fig. 4. Response curves of the L-glutamate sensor. Experiments were done in $50 \mathrm{mM}$ phosphate buffer (pH 7.0) at $28^{\circ} \mathrm{C}$ using monosodium L-glutamate as the sample.

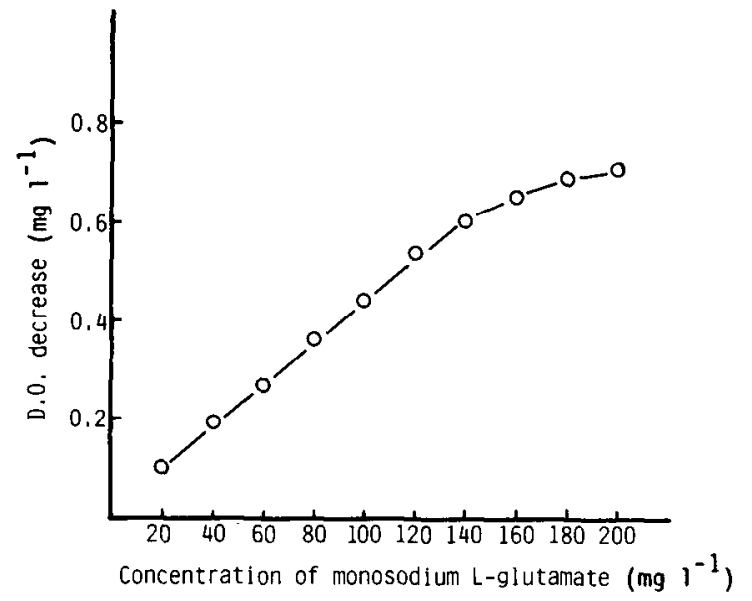

Fig. 5. Calibration graph for the L-glutamate sensor. Experiments were done in $50 \mathrm{mM}$ phosphate buffer (pH 7.0) at $28^{\circ} \mathrm{C}$ using monosodium L-glutamate as the substrate.

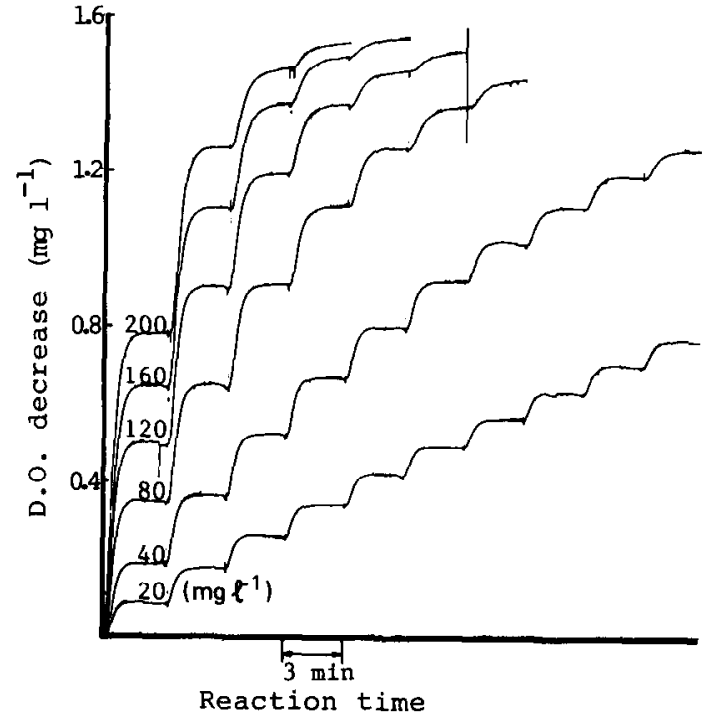

Fig. 6. Response curves of the L-glutamate sensor with stepwise increments in monosodium L-glutamate concentration. Experiments were done in $50 \mathrm{mM}$ phosphate buffer $(\mathrm{pH} \mathrm{7.0)}$ at $28^{\circ} \mathrm{C}$.

\section{Stability and reproducibility}

The sensor retained $95 \%$ of its original activity after 400 assays during 3 weeks. Four calibrations using standard monosodium L-glutamate solution were performed over the 3-week period. The results are given in Table 4 . The relative errors were less than $5 \%$ and the standard deviations were less than $0.03 \mathrm{mg}^{-1}$ for all data. On the basis of these results, the stability and reproducibility of the sensor were considered to be satisfactory.

TABLE 4

Reproducibility of the L-glutamate sensor ${ }^{\text {a }}$

\begin{tabular}{cllll}
\hline $\begin{array}{l}\text { Storage } \\
\text { period } \\
\text { (days) }\end{array}$ & $\begin{array}{l}\text { No. of times } \\
\text { sample } \\
\text { tested }\end{array}$ & $\begin{array}{l}\text { Average value of } \\
\text { D.O. decrease } \\
\left(\mathrm{mg} \mathrm{1}^{-1}\right)\end{array}$ & $\begin{array}{l}\text { Relative } \\
\text { error } \\
(\%)\end{array}$ & $\begin{array}{l}\text { Standard } \\
\text { deviation } \\
\left(\mathrm{mg} \mathrm{1}^{-1}\right)\end{array}$ \\
\hline 0 & 20 & $0.904 \pm 0.044$ & 4.87 & 0.0239 \\
6 & 17 & $0.902 \pm 0.028$ & 3.10 & 0.0184 \\
11 & 10 & $0.892 \pm 0.032$ & 3.59 & 0.0170 \\
17 & 14 & $0.880 \pm 0.030$ & 3.41 & 0.0187 \\
\hline
\end{tabular}

axperiments were done in $50 \mathrm{mM}$ phosphate buffer (pH 7.0), at $28^{\circ} \mathrm{C}$. $100 \mathrm{mg} \mathrm{l}^{-1}$ (ca. $0.6 \mathrm{mM}$ ) monosodium L-glutamate was used as the sample. 
TABLE 5

Determination of L-glutamic acid in fermentation broth with the sensor and by an enzymatic method using glutamate dehydrogenase $^{\text {a }}$

\begin{tabular}{llll}
\hline Sample & $\begin{array}{l}\text { Concentration of } \mathrm{L} \text {-glutamic } \\
\text { acid }(\%, w / v)\end{array}$ & $\begin{array}{l}\text { Relative } \\
\text { error } \\
\text { (\%) }\end{array}$ \\
\cline { 2 - 4 } & Enzymatic method & Sensor method & \\
\hline 1 & 1.02 & 1.11 & 8.82 \\
2 & 1.32 & 1.39 & 5.30 \\
3 & 1.79 & 1.81 & 1.12 \\
4 & 2.16 & 2.19 & 1.39 \\
5 & 2.53 & 2.52 & 0.40 \\
6 & 2.83 & 2.79 & 0.41 \\
7 & 3.46 & 3.41 & 1.45 \\
8 & 3.93 & 3.82 & 2.80 \\
\hline
\end{tabular}

${ }^{a}$ Experiments with the sensor were done in $50 \mathrm{mM}$ phosphate buffer (pH 7.0) at $28^{\circ} \mathrm{C}$. Glutamate dehydrogenase (E.C. 1.4.1.3) was used in the enzymatic method. The relative error was calculated by dividing the difference between the results obtained with the two methods by that obtained with the enzymatic method.

Comparison with a spectrophotometric method using glutamate dehydrogenase

The L-glutamate oxidase sensor was applied to determine the L-glutamate concentration of broth in a jar fermenter during L-glutamic acid fermentation. Samples were determined simultaneously with the sensor and using glutamate dehydrogenase [17]. The results are given in Table 5. The good correlations between the results obtained with the two methods indicate that the accuracy of this sensor is acceptable.

\section{Conclusion}

Although several enzymes have been used to construct L-glutamate sensors [8-12], the Lglutamate oxidase sensor appears to be promising because of its superiority in substrate specificity, quick response time and low cost of materials. The long-term stability of the sensor is fairly good in comparison with other techniques for process control of fermentation such as microbial sensors [18]. Related studies for the purpose of applying this sensor to monitor the accumulation of L-glutamic acid in fermentation broth continuously are in progress.
The authors express their appreciation to the National Science Council, Taiwan for providing research grants (NSC-77-0406-E002-07), to Miss M. Tseng, associate Microbiologist of the Culture Collection and Research Centre, Taiwan, for assisting in the identification of the microorganism, and to Dr. J.M. Cooper for his advice and for assistance with the English.

\section{REFERENCES}

1 P. Jurtshuk and L. McManus, Biochim. Biophys. Acta, 368 (1974) 158.

2 A. Matsuzaki, H. Suzuki, T. Kamei, K. Asano and S. Nakamura, Japanese Published Unexamined Patent Application (Kokai Tokyo Koho), 57-43685, 1982.

$3 \mathrm{H}$. Kusakabe, Y. Midorikawa, A. Kuninaka and $\mathbf{H}$. Yoshino, Agric. Biol. Chem., 47 (1983) 179.

4 C.Y. Chen, P.L. Chen and Y.C. Su, Nippon Nogeikagaku Kaishi, 64 (1990) 365

5 W.C. Chen, Doctoral Thesis of Graduate Institute of Chemical Engineering, National Taiwan University 1986, p. 54.

6 M. Hikuma, H. Obana, T. Yasuda, I. Karube and S. Suzuki, Anal. Chim. Acta, 116 (1980) 61.

7 S. Kuriyama and G.A.Rechnitz, Anal. Chim. Acta, 131 (1981) 90.

8 R. Januseviciute, B. Ceskis, A. Pauliukonis and D. Kazlauskas, Zh. Anal. Khim. 38 (1983) 498.

9 G.G. Guilbault and F. Shu, Anal. Chim. Acta, 56 (1971) 333.

10 T. Iida, T. Kawabe, F. Noguchi, T.Mitamura, K. Nagata and K. Tomita, Nippon Kagaku Kaishi, (1987) 1817.

11 T. Iida and T. Kawabe, Eur. Pat. Appl., EP 257919, 1988.

12 U. Wollenberger, F.W. Scheller, A. Böhmer, M. Passarge and H.G. Müller, Biosensors, 4 (1989) 381.

13 H. Kusakabe, Y. Midorikawa and T. Fujishima, Agric. Biol. Chem., 48 (1984) 181.

14 K. Nagata, K. Kurosaka and K. Tomita, Shokuhin To Kagaku, 29 (1987) 93.

15 H. Ishikawa, H. Misaki and N. Muto, Ger. Offen., DE $3307607,1983$.

16 Y.C. Su and C.Y. Chen, Proc. Natl. Sci. Counc. B, R.O.C., 11 (1987) 10.

17 E. Bernt and H.U. Bergmeyer, Methods of Enzymatic Analysis, Academic, New York, 1974, p. 1704.

18 I. Karube and S. Suzuki, Annual Reports on Fermentation Processes, Vol. 6, Academic, New York, 1983, p. 203. 